\title{
Molecular Technologies in Serbian Lowland Forestry under Climate Changes - Possibilities and Perspectives
}

\section{Branislav Trudić ${ }^{1}$, Saša Orlović ${ }^{1}$, Vladislava Galović ${ }^{1}$, Saša Pekeč ${ }^{1}$, Dejan B. Stojanović ${ }^{1}$, Srđan Stojnić ${ }^{1}$}

1 Institute of Lowland Forestry and Environment, University of Novi Sad, Antona Čehova 13, RS-21000 Novi Sad, Serbia

$\varangle$ Corresponding author: e-mail: btrudic@uns.ac.rs

Citation:

TRUDIĆ B, ORLOVIĆ S, GALOVIĆ V, PEKEČ S, STOJANOVIĆ DB, STOJNIĆ S 2014 Molecular Technologies in Serbian Lowland Forestry under Climate Changes - Possibilities and Perspectives. South-east Eur for 5 (2): 103-115. DOI: http://dx.doi.org/10.15177/seefor.14-10

\section{Abstract}

Background and Purpose: Vojvodina province, the northern part of the Republic of Serbia, is predominantly lowland agricultural region with over $75 \%$ of arable land which in previous years, has been highly impacted by drought. The annual precipitation is lower than $700 \mathrm{~mm}$ and it is the limit for the growth and development of natural forest vegetation. Unfortunately, the atmospheric precipitation is still a major source of water for plant biodiversity. Taking these facts into account, it is highly recommended to primarily use the xerothermic tree species, which have a well-developed root system for "classical" afforestation. Some species from Salicaceae and Fagaceae like poplars, willows, oaks and beeches are surely the best option for afforestation in temperate zones strongly influenced by drought.

Conclusions: In order to develop stress-based genomic information in Populus and the rest of woody plant species from Vojvodina, an integrated genetic research needs to be done. The aim of this particular paper is to analyse and summarize data regarding stress-based biotechnology perspectives in Vojvodina and to give recommendations for future forest tree breeding. Drought as a strong negative ecological factor must be carefully considered. In order to achieve sustainability, new forest management plans must consider wide approaches, from molecular to ecosystem level.

Keywords: abiotic stresses, climate changes, drought, transgenic trees, Vojvodina Province 


\section{INTRODUCTION - IMPORTANCE OF FORESTRY IN VOJVODINA}

In terms of global climate change, abiotic stresses (salinity, drought, temperature etc.) are major causes of loss of natural vegetation, agricultural cultivars and crops. Vegetation mortality in association with a high frequency of drought and an increased temperature has recently been documented on all six vegetated continents. When these observations are combined with forecasts of rising global temperature, declining regional precipitation and more extreme droughts, a scenario emerges in which many vegetation communities could be pushed past their mortality thresholds in coming decades [1].

Abiotic stress causes various morphological, physiological and molecular changes that affect plant growth and productivity. Managing abiotic stress is especially important to the long-term growth of tree species. Forests are particularly sensitive to climate change, because the long lifespan of trees does not allow for rapid adaptation to environmental changes [2].

This paper provides an overview of recent trends of lowland forestry research due to drought stress and warm temperatures in forests in Vojvodina, comparing with research trends in Europe. Climate as a driver of drought and directly responsible for tree mortality is also tackled, summarizing scientific understanding for assessing possible relationships between changing climate and forest conditions in lowland forestry of Serbia and worldwide. Note that while climatic events can damage forests in many ways, our emphasis is on environmentalinduced physiological stress driven by drought (decreased water availability in soil) and warm temperatures. The ecological effects of increased mortality in forests and the associated consequences for human society remain largely un-assessed.

We conducted a systematic search for published literature of forest stress-based biotechnology, using standard search engines and databases, such as ISI Web of Science, PubMed and Google Scholar. From the extensive set of documents, we used two specific criteria to determine whether the reference was appropriate for setting discussion and recommendations. Criteria for reference inclusion were:

1. usage of modern molecular methods and applicative results in forest tree species research, and

2. documentation of a strong correspondence between increases in mortality/drying/ senescence of forest tree species and increased water stress or high temperatures.

\section{ENVIRONMENTAL CHALLENGES AFFECTING FORESTRY IN SERBIA}

Europe is getting warmer above the rate of global average. Until 2007, the average annual temperature of the European land area had been $1.2{ }^{\circ} \mathrm{C}$ higher than in the preindustrial period, whereas in the combined land and sea area the temperature increased by $1{ }^{\circ} \mathrm{C}$. The projections of annual temperatures, established on the basis of climatic models designed for various climate change scenarios, estimate that the temperature will increase from 1 to $5.5^{\circ} \mathrm{C}$ by the end of this century. During winters, the highest warming is expected in the east and north, whereas in summers it is predicted in the south-west and Mediterranean part of Europe [2].

The Republic of Serbia is a landlocked country located in the Balkans and in the Pannonian plain. Climate of Serbia is of temperate continental type. Proximity of the mountain ranges of Alps, Carpathians, Rhodopes, as well as Adriatic Sea and Pannonian plain affect the climate. Average annual air temperature for the area with the altitude of up to $300 \mathrm{~m}$ amounts to $11{ }^{\circ} \mathrm{C}$. The areas with the altitudes of 300 to $500 \mathrm{~m}$ have average annual temperature of around $10.5^{\circ} \mathrm{C}$, and over $1000 \mathrm{~m}$ of altitude around $6{ }^{\circ} \mathrm{C}$. Precipitation, in lower regions, ranges in the interval from 540 to $820 \mathrm{~mm}$, areas on altitude over $1000 \mathrm{~m}$ receive in average 700 to $1000 \mathrm{~mm}$, and peaks of some mountains in south-western Serbia up to $1500 \mathrm{~mm}$. The major 
part of Serbia has continental precipitation regimen, with a peak in the early summer period, except for the southwest, which receives its highest precipitation in autumn [3]. Climate change scenarios predict increasing mean air temperature between 2.4 and $3.8^{\circ} \mathrm{C}$ until 2100 . Concerning precipitations, climate projections indicate an increase of precipitation for Serbia of 20 to $30 \mathrm{~mm}$ per year for 2001-2030 and a decrease of precipitation of up to $30 \mathrm{~mm}$ per year for 2071-2100, compared with 1961-1990 [3].

The domination of a negative trend of the annual air temperature in Serbia ceased in 1982. Since 1983, and particularly since 1987 , positive trends have been detected, first in shorter, and later in increasingly longer intervals. The intensity of decline of annual precipitation is $5 \%$ of the regular amount in 50 years. In Serbia, the beginning of the period of the air temperature increase is accompanied by a period of reduced annual precipitation sum [4].

Serbia contains 2.3 million ha of forests which cover approximately $29.1 \%$ of the total area. The dominant growing stock in Serbia are coppice forests with $64.7 \%$ of the total forest area, natural high stands cover $27.5 \%$, and artificially established stands (with plantations) cover $7.8 \%$. According to the National Forest Inventory, 49 tree species are identified in Serbia. Broadleaf species (40) dominate over coniferous species (9). The dominant species is beech and its percentage in total volume is $40.5 \%$, and in volume increment $30.6 \%$. The most represented coniferous species is spruce. Its percentage accounts for $5.2 \%$ of volume and $6.7 \%$ of volume increment [5].

Another distribution for Serbia's 2.3 million ha of forests means that $77 \%$ is in Central Serbia, $18.6 \%$ in Kosovo and Metohia and $4.4 \%$ in Vojvodina. These forests comprise willow (Salix fragilis L., and Salix alba L.), poplar (Populus spp.), pedunculate oak (Quercus robur L.), sessile oak (Quercus petraea (Matt.) Liebl.), Austrian oak (Quercus cerris L.), Hungarian oak (Quercus frainetto Ten.), narrow-leafed ash (Fraxinus angustifolia Vahl), alder (Alnus spp.), European hornbeam (Carpinus betulus L.), beech (Fagus moesiaca (Domin, Maly) Czeczott), pine (Pinus nigra Arn.), and mixed beech-fir (Abieti-Fagenion moesiacae, Jov. 1976), beechfir-spruce (Abieti-Piceenion Br. - Bl. 1939) and high-mountain spruce forests (Vaccinio-Piceion $\mathrm{Br}$ - Bl. 1939). Beech is the most frequent species (37\% of forest area), followed by oak (35\%), other deciduous species (20\%) and conifers (8\%, of which pines are the most prevalent species) [5].

The increase of forest cover percentage compared to the reference year 1979 is $5.2 \%$, which by all means had a positive effect on the state and quality of the environment in general. Negative human impact on forest is visible, especially, through the percentage of coppice forest. Signs of global change impact are pronounced in the cases of Pendunculate and Sessile oak, due to high percentage of tree declining in almost the entire area [3].

TABLE 1. Climate conditions in Serbia for several extremely dry years [6]

\begin{tabular}{ccccc}
\hline Year & $\begin{array}{c}\text { Temperature } \\
\text { April - October } \\
\left({ }^{\circ} \mathrm{C}\right)\end{array}$ & $\begin{array}{c}\text { Precipitation } \\
\text { April - October } \\
(\mathrm{mm})\end{array}$ & $\begin{array}{c}\text { Temperature } \\
\text { Yearly } \\
\left({ }^{\circ} \mathrm{C}\right)\end{array}$ & $\begin{array}{c}\text { Precipitation } \\
\text { Yearly } \\
(\mathrm{mm})\end{array}$ \\
\hline 2012 & 18.4 & 367.0 & $/$ & $/$ \\
2011 & 17.1 & 300.5 & 10.8 & 469.8 \\
2007 & 17.0 & 454.6 & 11.6 & 775.3 \\
2003 & 17.1 & 421.5 & 10.8 & 606.3 \\
2000 & 17.7 & 262.0 & 11.9 & 436.8 \\
$1961-1990$ & 15.6 & 437.1 & 10.0 & 690.7 \\
\hline
\end{tabular}




\section{FORESTRY OF VOJVODINA UNDER DROUGHT STRESS}

In the Vojvodina region which is predominantly agricultural region with over $75 \%$ of arable land, drought can have considerably negative impact on agricultural production. As a consequence of the insufficiently developed irrigation systems, the atmospheric precipitations are still the major factor in providing water to the soil and crops. In a greater or lesser intensity, drought occurs almost every year and it is the limiting factor of high yields $[4,7]$.

It was estimated that $13.2 \%$ of the territory of Vojvodina, located mostly in the central and southeast parts, is highly vulnerable to drought. The main reasons for this are the occurrence and long duration of severe droughts. Recurrence times of the severe droughts vary from 12.2 to 15.4 months. Regions with the most frequent severe drought occurrences are the eastern parts of Vojvodina (municipalities: Kikinda, Zrenjanin, Vršac), northern areas around Palić and southwest area around Sremska Mitrovica. Residence times of severe drought are ranging from 1.7 to 2.2 months. Longest durations of severe droughts are in central areas around cities of Novi Sad and Zrenjanin. The most vulnerable regions to drought are central, southeast and southwest parts of Vojvodina $[7,8]$.

The analysis of climate characteristics of Vojvodina shows that there are conditions for the development of forest vegetation. Taking into account the annual precipitation of 550 to $670 \mathrm{~mm}$, which is somewhat lower than $700 \mathrm{~mm}$, which is the limit for the occurrence of natural forest vegetation, it is recommended to use primarily the xerothermic tree species, which have a well-developed tap root, except in the areas along the natural and artificial watercourses, where the hygrophilous tree species would be the most favourable species for the establishment of plantations and forests $[9,10]$.

The selection of species for forests establishment depends on the above mentioned climate, hydrological and soil conditions and potential natural vegetation in Vojvodina [9,
10]. The most representative species for the hydromorphic soil type is common oak and highly productive varieties of poplar. The halomorphic soil type, due to unfavourable site conditions, supports very few woody species, of which the author recommends common oak, based on the potential vegetation. Reports from Jovanović [11] on chernozem and meadow black soil, as the most represented soil types in Vojvodina, the optimal species is $Q$. robur, and the recommended species are the clones of Populus albae and the xerothermic fruittree species. A wider spectre of species in the genera Populus, Acer, Morus, Tilia, Coryllus, Betula, Hypocastanum, Fraxinus and Juglans is recommended on meadow black soil thanks to the moister soils. For hydromorphic black soils, the above authors recommend hygrophilic species, mainly in the genera Populus and Salix, while on brown forest soil, the advantage is given to the species Quercus petrea, Quercus cerris and Tilia argentea for the tree layer and Acer campestre, Carpinus betulus, Corylus avellana, Sambucus nigra, and Cornus sanquinea for the shrub layer. On other soils, such as arenosol which prevails in the sands of Deliblatska Peščara and Subotička Peščara, the protection and economic forest plantations should mainly consist of xerothermic tree species, of which the best are Robinia pseudoaccacia, Pinus nigra and Populus alba [10].

\section{BREEDING POTENTIAL OF POPLARS DUE TO DROUGHT STRESS}

Trees have evolved various mechanisms which help them to cope with limited water supply. Responses to drought include:

1. reducing the water deficit by developing root systems able to take up water deeper in the soil;

2. minimizing water losses through stomatal closure and producing small leaves;

3. accumulating osmoprotective substances $[12,13]$.

Poplars are truly multipurpose tree species. They provide a nearly endless list of wood and 
fiber products, non-wood products, and are grown increasingly in bioenergy plantations for firewood. They have a positive role in the rehabilitation of degraded lands, forest landscape restoration and climate change mitigation [14].

Poplars are potentially the best option to increase biomass production in temperate zones, such as Vojvodina in the Republic of Serbia, but there is a need to identify clear objectives on how to use this material in the forestry wood chain. In the past, growth, disease resistance and adaptation to climatic conditions have been the major drivers for selection and breeding of poplars. Improved material characterization as well as high throughput methodology to support selection and breeding will allow future strategic decisions for afforestation of fast growing species in the Vojvodina province [15]. Populus nigra, that establishes naturally within or along the active channel and that is strictly dependent of the morphodynamics of the Danube River, will be exposed to three new threats:

(i) enhancement of the frequency and severity of drought with summer decrease of the water level, which is extremely noticeable in recent years,

(ii) extreme heat waves, especially in summer (temperature is a key factor for survival and development of seedlings) and

(iii) more intense flooding [16].

Populus nigra L. is important species of the European alluvial forests that are protected under Habitats directive 92/43/EEC in entire Europe. This species is often regarded as a good indicator of geomorphological and biological quality of this ecosystem and is an active support of riparian biodiversity. This species is also threatened by anthropogenic disturbances and gene introgression, justifying French and European (EUFORGEN) programme on in situ and ex situ conservation of its genetic resources [16]. This species is common on the territory of Vojvodina province, having the same importance for domestic agriculture production, forest and environmental management.

Young poplar trees (Populus deltoides, Dvina and Populus x canadensis, 1-214) were grown under reduced soil water availability. The stress intensity was estimated by measuring soil water content, predawn leaf water potential, leaf relative water content, leaf growth, leaf conductance and maximum photosynthesis, maximum daily shrinkage of the stem. Radial growth was recorded by point dendrometers and the effect of water deficit on differentiating xylem and wood was investigated by high resolution stem growth analysis and anatomical investigation. After 16 days of withholding irrigation, significant differences were recorded between treatments and genotypes in term of leaf RWC (Relative Water Content), total leaves number, total leaf area increase and stem length increase. On the basis of results, the hybrid I-214 has showed a higher susceptibility to water stress than Dvina [17].

Poplar transformed with a gene for pine cytosolic glutamine-synthesise isozyme (GS1; look at NCBI: P52783) was shown to be more tolerant to drought stress than wild-type trees. At all levels of water availability, the transgenic trees had higher photosynthetic assimilation rates and stomatal conductance than the corresponding controls. All GS1-containing lines also showed an irreversible decline in photosystem II (PSII) antennae transfer efficiency after drought and during recovery, but the increased photo-assimilation capacity of the transgenic poplar allowed more resources to be allocated to photo-protective mechanisms [18].

\section{PLANT LIFE SCIENCE RESEARCH AS A BASIS FOR FOREST STRESS-BASED BIOTECHNOLOGY}

Responses of plants to stress may be revealed at a whole plant level as an integrated tissue system, while some of the responses occur at the cellular level. For example, closing of stomata results from subtle biochemical and molecular changes in the guard cell itself but this event is ultimately induced by the signalling transduced by other cells like root cells. Sometimes a comparison between cellular response and whole plant response may reveal 
the level of organization where the adaptation operates. In the contrary, seed germination and seedling growth declines with increasing water stress, while proteolysis in cotyledons during storage mobilization is retarded by water stress. Metabolic changes that occur in plants, particularly mesophytes, in response to water stress have been major targets of research interest while searching for molecular mechanism of stress tolerance. Such studies have been strengthened further with the aid of molecular tools like microarray and differential expression of genes [19].

On molecular level, drought stress also induces reactive oxygen species (hereinafter: ROS) generation as a primary response of plant. Gross level of ROS could facilitate the stress induced damages to most of the cellular components, unless compromised by plant antioxidant system. However, depending on spatial and temporal ROS generation and scavenging, responses can be characterized as toward conferring protection by arousing the protection system or as directly leading to injuries or death. Gradual imposition of drought stress, which is more common in nature, probably triggers ROS generation in the apoplast by plasma membrane-localized NADPH oxidase, where $\mathrm{Ca}^{2+}$ plays a role as an upstream as well as downstream messenger forming a positive feedback loop [19]. Effects of drought-induced generation of ROS in poplar and concomitant induction of ROS detoxifying enzymes in leaves have been investigated [20-22]. Morabito and Guerrier [23] found that roots are the most sensitive organ of poplar to oxidative stress after $12 \mathrm{~h}$ drought, but nothing is known about reactions in roots after longer drought events [13].

There is an enormous potential for speeding up tree breeding cycles by the use of genetic modification. Systems have been developed for gene transfer, selection of novel gene-containing shoots and stimulating regeneration for both broadleaved and coniferous trees $[24,25]$.

Comprehensive analysis of the relationship between the transcriptome of homologous Arabidopsis and Populus genes facilitates to identify the correlation of the response systems and the roles of the homologues among the species [13].

The plant-specific GRAS/SCL transcription factors play diverse roles in plant development and stress responses. Poplar SCL (SCARECROWLIKE) gene, PeSCL7, was functionally characterized in Arabidopsis thaliana, especially with regard to its role in abiotic stress resistance. Expression analysis in poplar revealed that PeSCL7 was induced by drought and high salt stresses, but was repressed by gibberellic acid (GA) treatment in leaves. Transgenic Arabidopsis plants over-expressing PeSCL7 showed enhanced tolerance to drought and salt treatments. These results suggest that PeSCL7 encodes a member of the stress-responsive GRAS/SCL transcription factors that is potentially useful for engineering of drought- and salt-tolerant trees [26].

The expressed small RNAs from leaves and vegetative buds of Populus have been isolated using high throughput pyrosequencing [27]. By the analysis, almost 80000 small RNAs were identified with 123 novel small RNAs belonging to previously identified miRNA families from other plant species and 48 novel miRNA families that could be Populus-specific [27]. The putative target genes of Populus-specific small RNA were involved in development and resistance to stress. Lu et al. $[28,29]$ have identified abiotic stressresponsive miRNAs from $P$. trichocarpa, whose expression was altered in response to cold, heat, salt, dehydration and mechanical stresses. Some of these stress-responsive miRNA families are conserved among various plant species, such as Arabidopsis, rice and poplars. The other Populus or tree-specific miRNAs were also identified and predicted to function in the adaptation to longterm growth and survival from stress conditions in woody plants [30].

\section{FOREST GENETIC AND BREEDING RESEARCH IN SERBIA}

Despite the area of forests of Vojvodina province are just $4.4 \%$ of total forest area of Serbia, it still presents huge agricultural potential 
for Serbia, especially its continental-temperate zone with a unique opportunity for some species to grow (Salicaceae species, Quercus species etc.).

First studies on examination of molecular markers and adaptive traits of forest tree species in Serbia, in order to accelerate the selection process of poplar and willow, as well as to define critical parameters in the growth process, were designed at the Institute of Lowland Forestry and Environment, University of Novi Sad. Forest breeding programs at the Institute of Lowland Forestry and Environment, University of Novi Sad, have until now been based only on conventional clonal identification system, meaning the combinational research of morphological and phenological traits characterization [31]. Revealing and characterizing genetic background of poplar clones, using molecular markers systems like AFLPs and SSRs, is one of the major contributors to novel taxonomy and breeding perspectives for woody plant species in Vojvodina province. While AFLP markers have been utilized in evaluating hybrids and in parentage assessment in many other species [32-35], the highly polymorphic, consistent and co-dominant markers, such as SSRs, are excellent markers for clone and cultivar identification in poplars so far $[36,37]$.

To begin dissecting genome information in Populus, integrated genetic and gene expression data needs to be done, with phenotypic traits measured in populations of $P$. deltoides and $P$. nigra, which are common for Vojvodina province and some parts of Western Balkans. In recent years, studies of forest genetic resources in Serbia were conducted on numerous tree species. Researches of molecular markers were focused mainly on investigation of genetic diversity in natural populations of European beech [38], Austrian pine and Scots pine [39-42], Serbian spruce [43], Sorbus spp. [44] and Sessile oak [45]. Numerous research on investigation of variability of adaptive traits were conducted in the natural populations of Wild cherry $[46,47]$.

Research in the European beech provenance trials were aimed on analysis of variability of leaf anatomical, physiological, biochemical and morphological traits. Some results have been published to date $[48,49]$. Research in the beech provenance trials were also aimed on investigation of environmental conditions in the provenance trials [48].

Various reports of forest management from Srem region of Vojvodina province in the Republic of Serbia showed that some parts of the population of Pendunculate oak are endangered, under the influence of environmental aridity. To determine the genetic basis of senescence caused by drought, the system of molecular analysis needs to be performed in order to make recommendations for developing new strategies to preserve the oak gene pool. Specifically, the aim of these pioneer experiments would be to target candidate genes responsible for senescing and drought stress tolerance of Pendunculate oak from Srem [50-52].

Nonić et al. [53] reported the results of monitoring and collecting information on public opinion, analysis of laws and legislation regarding genetically modified plants and possibilities of scientific research on transgenic tree species in several European countries. The proposed survey included results from 8 countries (Italy, Slovenia, Romania, Bulgaria, Serbia, Croatia, Montenegro and Bosnia and Herzegovina), aiming to contribute to the common future of EU policy in this field. First results indicate that public opinion is divided and provide a good basis for understanding the issue of implementation of stress-based transgenic technology, in order to define clear scientific attitude as a recommendation, both in EU member states and Western Balkans countries.

\section{Poplars Oxidative Stress and Functional Genomic Research in Vojvodina}

The effect of different concentrations of three heavy metals ions, $\mathrm{Cu}^{2+}, \mathrm{Ni}^{3+}$ and $\mathrm{Cd}^{2+}$, on oxidative stress in three poplar clones (PE 19/66, M1 and B229), from two different species, Populus deltoides (Marshall) and Populus euramericana (Dode-Guinier) were analysed. Possible antioxidant capacity of these clones in response to different concentrations of heavy metals ions in substrate was measured in order to find which clone is most appropriate for 
phytoremediation processes. Results showed variable responses within poplar leaves and roots in response to oxidative stress induced by heavy metals and the most promising clone for phytoremediation of contaminated soils is B229 clone, while M1 and PE 19/66 showed variable antioxidant response [54]. Another study on oxidative stress profiles of three mentioned poplar clones shoots [55], while being treated by the same heavy metal stress treatment, showed that the most acceptable phytoremediation response to the pollution in soil showed clone M1. PE 19/66 clone in both studies resulted as not being suitable for possible phytoremediation application of contaminated soils by heavy metals.

Also, another study included also poplar clones PE 19/66, B229 and clone Panonia (Populus $x$ euramericana) regarding induced oxidative stress in leaves after treatments with heavy metals, herbicides, diesel fuel, as well as a mixture of heavy metals and diesel fuel in the experimental field. Biochemical responses to the induced stress were estimated by using in vitro tests for determination of radical scavenger capacity and total antioxidant activity, DPPH and FRAP test. Obtained results showed great correlation between antioxidant and scavenger activities of poplar clones extracts which shown increased both activities under the applied treatments. Treatment of combined stress inducers (heavy metals and diesel fuel) showed synergistic effect upon all clones for both determined tests comparing to separately applied stressors. Clone B-229 showed indication of higher tolerance to applied stressors compared to other clones [56]. These oxidative stress screening tests showed the possibility of poplars genotypes for afforestation of contaminated areas and soils in Serbia. Climate changes are causing various abiotic and biotic stresses in environment, also changing the life cycle of various contaminants.

The study of Štajner et al. [57] was designed to examine and compare antioxidant and freeradical scavenging activities of leaves of six different melliferous plant species (Populus alba, Robinia pseudoacacia, Sophora japonica, Euodia hupehensis, Tilia sp., Fraxinus sp.) from
Serbia in order to evaluate their drought-induced oxidative stress tolerance. An experiment was conducted during June, July and August. In this study, they reported the results concerning proline accumulation, soluble protein content, quantities of malonyldialdehyde, total antioxidant capacity determined by FRAP method and scavenger activity determined by DPPH method. According to the results, all melliferous plant species were subjected to drought, leading to oxidative stress during July when soil humidity decreased. During July, proline content and MDA quantity increased and soluble proteins decreased in all investigated species. High and permanent antioxidant activity during the whole investigated period was observed in $P$. alba, but insufficient to protect its leaves from oxidative injury during the period of drought in July.

On ILFE, functional genomic approach was applied, to have insight into the oxidative stress responses of Serbian poplar clones with different genetic background. The objective was to identify genes with altered transcript accumulation during salt stress and to characterize their expression [58]. Genetic transformation gives the possibility to achieve various applied goals in plant stress biotechnology. Recent publications related to salt and drought-inducible poplar GRAS protein SCL7 showed that this gene is potentially useful for engineering drought and salt tolerance in trees, thus directing our attention to a GRAS/ SCL transcription factor (TF) as a candidate gene of interest. After DNA sequence polymorphisms were described within Serbian species by their SNPs patterns and the number of polymorphic sites was revealed, one step forward was made toward genetic transformation of the same poplar clones for GRAS/SCL. For this study,two different agronomically important clones, ( $P$. deltoides and $P . x$ euramericana) were sampled. PCR (either with genomic or CDNA) with primers for Gateway clonning from PtGRAS/ SCL7 TF exon part was successfully done and fragments of $P$. deltoides and $P$. $x$ euramericana were obtained and ligated using BP clonase into $\mathrm{PDONR}$ vector. This is the preliminary result toward improvement in tolerance to abiotic stresses in poplar species [59]. 
While many potential benefits can be envisioned and have been described for genetic engineering in forest trees, there are also risks and they must be thoroughly evaluated. These risks can be placed into two general categories:

1. risks to plantations of transgenic trees;

2. risks associated with the migration of transgenes (i.e., gene flow) into neighbouring environments.

The second type of risk entails transgenes migrating and either reducing or increasing the fitness of trees in the recipient populations. Transgenes are packed in genotypes that combine to produce phenotypes that the environment acts on. Furthermore, the potential for these genes to migrate into the same or related species by gene flow (i.e., pollen or seed movement) must also be evaluated $[60,61]$.

An alternative to minimize gene flow is the use of sterile genetically modified trees. Many efforts have been put in facilitating research and understanding genes involved in the flowering process of trees $[62,63]$. The use of transgenic trees in the forestry sector has very different objectives than those used for crops. They are mainly based in improving wood quality, so as to diminish the pressure on the land. The genes involved in these processes are quite specific and are mainly present in trees; therefore its possible escape to the environment does not have a major risk [64].

\section{FUTURE OF FORESTRY IN VOJVODINA}

An in-depth understanding of the physihological stress responses and the molecular events in woody plants, which are some of the major components of the global ecosystem and biomass resources, will always be required. The findings reviewed here would contribute to understanding of the possible need of the introduction of stress-based biotechnologies to control stress responses of forest tree species in Vojvodina province, Republic of Serbia. Developing the stress-tolerant woody plants models and practices would require further understanding of various aspects of the molecular responses under the stress conditions. The main objectives for future sustainable forest policy of Vojvodina Province are to increase the area and vitality of the forests (through afforestation, reclamation and cultivation), to create the technical base for all types of forestry work, to maximize financial returns [65] and to start develop transgenic technologies for research purposes with the goal to cope with extreme drought waves on this territory.

Whichever aspects of transgenic technologies advance most rapidly in the future, environmental risk assessment should always be carried out, on a case-by-case basis, until a sufficient body of knowledge on the anticipated benefits and the possible risks of this exciting technology are established [66]. Possible introducing new sterile transgenic plant tree species into arid area may be seen as an important way forward. This genetic strategy of developing transgenic species of forest plant species will enable sustainable forest ecosystems that will allow continued production of necessary oxygen and accelerate the elimination of harmful carbon dioxide emissions that cause the greenhouse effect and thus affect global warming and imbalance the level of the entire plant layer on the planet Earth. Drought is still causing negative environmental and economic consequences in all of Serbia, especially in the Vojvodina province and decision makers need to improve planning of mitigation practices and future sustainable forestry management on molecular level, especially for one of the most important woody plant species for that particular Serbian region: poplar, willow, oak and beech species [48].

Construction of gene banks responsible for different aspects of resistance of all tree species to a variety of abiotic stresses should become an imperative for sustainable agroforestry that can respond to various environmental challenges which is facing today and will face in the future. The greatest challenge facing humanity in the field of controlled and responsible production of transgenic trees is the ethical approach and a clear intention to help and develop the planet in the upcoming climatic challenges. 


\section{Acknowledgments}

This paper was realized as a part of the project "Studying climate change and its influence on the environment: impacts, adaptation and mitigation" (III 43007) financed by the Ministry of Education, Science and Technological Development of the Republic of Serbia within the framework of integrated and interdisciplinary research for the period 2011-2014. Also, great contribution to this paper was done during the COST Action FP0905 "Biosafety of forest transgenic trees" and COST Action FP1202 "Strengthening conservation: a key issue for adaptation of marginal/ peripheral populations of forest tree to climate change in Europe (MaP-FGR) ".

\section{REFERENCES}

1. MCDOWELL $N$, BEERLING $G$, BRESHEARS $D$, FISHER D, KENNETH R, RAFFA F, STITT M 2011 The interdependence of mechanisms underlying climate-driven vegetation mortality. Trends Ecol Evol 26 (10): 523-532. DOI: http://dx.doi. org/10.1016/j.tree.2011.06.003

2. LINDNER $M$, MAROSCHEK $M$, NETHERER $S$, KREMER A, BARBATI A, GARCIA-GONZALO J, SEIDL R, DELZON S, CORONA P, KOLSTRO M, LEXER MJ, MARCHETTI M 2010 Climate change impacts, adaptive capacity, and vulnerability of European forest ecosystems. Forest Ecol Manag 259 (4): 698-709. DOI: http://dx.doi.org/10.1016/j. foreco.2009.09.023

3. STOJNIĆ S, ORLOVIĆ S, PILIPOVIĆ A, STOJANOVIĆ D, TRUDIĆ B 2013 Serbia-National Report, FPS COST Action FP1202. Strengthening conservation: a key issue for adaptation of marginal/peripheral populations of forest tree to climate change in Europe (MaP-FGR). FAO, First Plenary Meeting, Via delle Terme di Caracalla - Roma, Italy, 22- 25 January 2013

4. URL: http://www.un.org/esa/agenda21/natlinfo/ countr/serbia/drought.pdf (15 June2014)

5. BANKOVIĆ $S$, MEDAREVIĆ M, PANTIĆ D, PETROVIĆ $\mathrm{N}$ (eds) 2009 National Forest Inventory of the Republic of Serbia (in Serbian). Ministry of Agriculture, Forestry and Water Management of the Republic of Serbia, Forest Directorate, Belgrade, Serbia, $238 p$

6. STOJANOVIĆ DB, KRŽIČ A, MATOVIĆ B, ORLOVIĆ S, DUPUTIE A, DJURDJEVIĆ V, GALIĆ Z, STOJNIĆ S 2013 Prediction of the European beech (Fagus sylvatica L.) xeric limit using a regional climate model: An example from southeast Europe. Agr Forest Meteorol 176: 94-103. DOI: http://dx.doi. org/10.1016/j.agrformet.2013.03.009
7. SPASOV P 2003 The occurrence of drought in Serbia, its monitoring and prediction capabilities. Vodoprivreda 35 (1-2): 30-36

8. URL: http://balwois.com/2012/USB/papers/299.pdf (15 June2014)

9. PEKEČ S, IVANIŠEVIĆ P, RONČEVIĆ S, KOVAČEVIĆ B, MARKOVIĆ M 2008 Plan and program of shelterbelts establishment in Vojvodina (in Serbian with English summary). Topola (Poplar) 181/182: 61-70

10. PEKEČ $S$, IVANIŠEVIĆ P, ORLOVIĆ $S$, GALIĆ $Z$ 2010 Possible use alkalized soil to increase afforestation area in Banat region. In: Rakonjac Lj (ed) International Scientific Conference "Forest ecocsystem and climate changes", Belgrade, Serbia, 9-10 March. Institute of Forestry, Belgrade, Serbia, vol II, pp 143-147

11. JOVANOVIĆ S 1965 Forest belts (in Serbian). Belgrade, Serbia

12. KOZLOWSKI TT, PALLARDY SG 2002 Acclimation and adaptive responses of woody plants to environmental stresses. Bot Rev 68 (2): 270334. DOI: http://dx.doi.org/10.1663/00068101(2002)068[0270:AAAROW]2.0.CO:2

13. REGIER N, STREB S, COCOZZA C, SCHAUB M, CHERUBINI P, ZEEMAN SC, FREY B 2009 Drought tolerance of two black poplar (Populus nigra L.) clones: contribution of carbohydrates and oxidative stress defense. Plant Cell Environ 32 (12): 1724-1736. DOI: http://dx.doi.org/10.1111/ j.1365-3040.2009.02030.x

14. KOLLERT W, DEL LUNGO A 2010 The contribution of poplar-science and technology to sustain rural livelihoods in developing countries. In: Poplars and Willows: from research models to multipurpose trees for bio-based society, Book of abstracts of Fifth International Poplar Symposium, Palazzo dei Congressi, Orvieto, Italy, 20-25 September 2010 
15. TRUDIĆ B, GALOVIĆ $V$, ORLOVIĆ $S$, PEKEČ $S$, KLAŠNJA B 2012 Possibility for developing of poplar tolerant to drought in Republic of Serbia. In: Book of abstracts of 24th International Poplar Commission, Dehradun, India, pp 57

16. VILLAR $M$, CHAMAILLARD S, BARBAROUX C, BASTIEN C, BRIGNOLAS F, FAIVRE RAMPANT P, FICHOT R, FORESTIER O, JORGE V, RODRIGUES S 2010 Populus nigra as keystone species able to cope with the ongoing climate change, France. In: Poplars and Willows: from research models to multipurpose trees for bio-based society, Book of abstracts of Fifth International Poplar Symposium, Palazzo dei Congressi, Orvieto, Italy, 20-25 September 2010

17. GIOVANNELLI A, EMILIANI G, TRAVERSI LM, CHIARABAGLIO PM, PALLARA G, RACCHI ML 2010 Effect of water deficit on wood formation of poplar clones: physiological and transcriptional analysis in cambial region, Italy. In: Poplars and Willows: from research models to multipurpose trees for bio-based society, Book of abstracts of Fifth International Poplar Symposium, Palazzo dei Congressi, Orvieto, Italy, 20-25 September 2010

18. FAO 2010 Forests and genetically modified trees. Food and Agriculture Organization of the United Nations, Rome, Italy, 235 p. URL: http://www.fao. org/docrep/013/i1699e/i1699e.pdf (8 April 2014)

19. KUMAR KAR R 2011 Plant responses to water stress.-Role of the reactive oxygen species. Plant Signal Behav 6 (11): 1741-1745. DOI: http:// dx.doi.org/10.4161/psb.6.11.17729

20. GUERRIER G, BRIGNOLAS F, THIERRY C, COURTOIS M, KAHLEM G 2000 Organic solutes protect drought-tolerant Populus $\times$ euramericana against reactive oxygen species. J Plant Physiol 156 (1): 93-99. DOI: http://dx.doi.org/10.1016/S01761617(00)80277-1

21. LEI Y, YIN C, LI C 2006 Differences in some morphological, physiological, and biochemical responses to drought stress in two contrasting populations of Populus przewalskii. Physiol Plantarum 127 (2): 182-191. DOI: http://dx.doi. org/10.1111/j.1399-3054.2006.00638.x

22. MARRON N, MAURY S, RINALDI C, BRIGNOLAS F 2006 Impact of drought and leaf development stage on enzymatic antioxidant system of two Populus deltoides $\times$ nigra clones. Ann For Sci 63 (3): 323-327. DOI: http://dx.doi.org/10.1051/ forest:2006012
23. MORABITO D, GUERRIER G 2000 The free oxygen radical scavenging enzymes and redox status in roots and leaves of Populus $x$ euramericana in response to osmotic stress, desiccation and rehydration. J Plant Physiol 157 (1): 74-80. DOI: http://dx.doi.org/10.1016/S0176-1617(00)80138-8

24. GARTLAND KMA, CROW RM, FENNING TM, GARTLAND JS 2003 Genetically modified trees: production, properties, and potential. Journal of Arboriculture 29 (5): 259-266

25. WENCK AR, QUINN M, WHETTEN RW, PULLMAN G, SEDEROFF R 1999 High-efficiency Agrobacteriummediated transformation of Norway spruce (Picea abies) and loblolly pine (Pinus taeda). Plant Mol Biol 39 (3): 407-416. DOI: http://dx.doi. org/10.1023/A:1006126609534

26. HONG-SHUANG MA, DAN L, PENG S, XIN-LI $X$ WEI-LUN Y 2010 The salt- and drought-inducible poplar GRAS protein SCL7 confers salt and drought tolerance in Arabidopsis thaliana. J Exp Bot 61 (14): 4011-4019. DOI: http://dx.doi.org/10.1093/ jxb/erq217

27. BARAKAT A, WALL PK, DILORETO S, DEPAMPHILIS CW, CARLSON JE 2007 Conservation and divergence of microRNAs in Populus. BMC Genomics 8: 481. DOI: http://dx.doi.org/10.1186/1471-2164-8-481

28. LU S, SUN YH, CHIANG VL 2008 Stress-responsive microRNAs in Populus. Plant J 55 (1): 131151. DOI: http://dx.doi.org/10.1111/j.1365313X.2008.03497.x

29. LU SF, LI LG, YI XP, JOSHI CP, CHIANG VL 2008 Differential expression of three eucalyptus secondary cell wall-related cellulose synthase genes in response to tension stress. J Exp Bot 59 (3): 681-695. DOI: http://dx.doi.org/10.1093/jxb/ erm350

30. OSAKABE Y, KAJITA S, OSAKABE K 2011 Genetic engineering of woody plants: current and future targets in a stressful environment. Physiol Plantarum 142 (2): 105-117. DOI: http://dx.doi. org/10.1111/j.1399-3054.2011.01451.x

31. ORLOVIĆ S, KLAŠNJA B, IVANIŠEVIĆ P 1997 Anatomical and physiological research in poplar breeding program (in Serbian with English summary). Topola (Poplar) 159/160: 69-80

32. VAN TOAI TT, PENG JST, MARTIN S 1996 Using AFLP markers to determine the contribution of parental genomes during recurrent selection. Soybean Genetics Newsletter 23: 214-216 
33. KRAUSS SL 2000 Patterns and mating in Persoonia mollis (Proteaceae) revealed by an analysis of paternity using AFLP: implications for conservation. Aust J Bot 48 (3): 349-356. DOI: http://dx.doi. org/10.1071/BT98082

34. GALOVIĆ V, MLADENOVIĆ-DRINIĆ S, JELOVAC D, NAVALUŠIĆ J 2004 Application possibilities of AFLP fingerprinting technique in maize DNA profiling and plant variety protection. Genetika 36 (2): 133-142. DOI: http://dx.doi.org/10.2298/GENSR0402133G

35. GALOVIĆ V, MLADENOVIĆ-DRINIĆ S, NAVALUŠIĆ J, ZLOKOLICA M 2006 Characterization methods and fingerprinting of agronomical important crop species. Genetika 38 (2): 83-96. DOI: http://dx.doi. org/10.2298/GENSR0602083G

36. GALOVIĆ V, ORLOVIĆ S, KOVAČEVIĆ B, PILIPOVIĆ A 2008 Microsatellite genetic relationships of Populus species clones, cultivars and hybrids from two sections of genus Populus. In: Orlović S (ed) Proceedings of International Scientific Conference Forestry in Achieving Millennium Goals, Novi Sad, Serbia, 13-15 November 2008. Institute of Lowland Forestry and Environment, Novi Sad, Serbia, pp 325-330

37. ORLOVIĆ S, GALOVIĆ V, ZORIĆ M, KOVAČEVIĆ B, PILIPOVIĆ A, GALIĆ Z 2009 Evaluation of interspecific DNA variability in poplars using AFLP and SSR markers. Afr J Biotechnol 8 (20): 52415247

38. IVETIĆ V, ISAJEV V, NIKOLIĆ A, KRSTIĆ M, RISTIĆ D, KOSTADINOVIĆ M 2012 Delineation of beech provenance regions in Serbia by spatial analysis of genetic diversity. Genetika 44 (1): 101-108. DOI: http://dx.doi.org/10.2298/GENSR12011011

39. ISAJEV V, MLADENOVIĆ-DRINIĆ S, LUČIĆ A 2008 The use of molecular markers in the improvement of conifer tree species (in Serbian with English summary). Bulletin of the Faculty of Forestry 98: 7-24. DOI: http://dx.doi.org/10.2298/GSF0898007I

40. LUČIĆ A, ISAJEV V, RAKONJAC L, RISTIĆ D, KOSTADINOVIĆ M, BABIĆ V, NIKOLIĆ A 2011 Genetic divergence of Scots pine (Pinus sylvestris L.) populations in Serbia revealed by RAPD. Arch Biol Sci 63 (2): 371-380. DOI: http://dx.doi.org/10.2298/ ABS1102371L

41. LUČIĆ A, ISAJEV V, RAKONJAC U, MATARUGA M, BABIĆ V, RISTIĆ D, MLADENOVIĆ-DRINIĆ S 2011 Application of various statistical methods to analyze genetic diversity of Austrian (Pinus nigra Arn.) and Scots pine (Pinus sylvestris L.) based on protein markers. Genetika 43 (3): 477-486. DOI: http://dx.doi.org/10.2298/GENSR1103477L
42. LUČIĆ A, NIKOLIĆ A, MLADENOVIĆ-DRINIĆ S, ISAJEV V, LAVADINOVIĆ V 2008 Genetic characterisation of genotypes of Austrian pine (Pinus nigra Arnold) populations using protein markers. Genetika 40 (2): 157-168. DOI: http://dx.doi.org/10.2298/ GENSR0802157L

43. MILOVANOVIĆ J, ŠIJAČIĆ-NIKOLIĆ M 2010 Characterization of Serbian spruce variability applying isoenzyme markers. Biotechnol Biotec Eq 24 (1): 1600-1605. DOI: http://dx.doi.org/10.2478/ V10133-010-0012-8

44. GALOVIĆ V, ORLOVIĆ S, TRUDIĆ B, PEKEČ S, VASIĆ S 2012 Intra-loci polymorphism of Sorbus spp. on the territory of Republic of Serbia (in Serbian with English summary). Topola (Poplar) 189/190: 87-97

45. ŠIJAČIĆ-NIKOLIĆ M, MILOVANOVIĆ J, BOBINAC M, SAVIĆ-PAVIĆEVIĆ D, BRAJUŠKOVIĆ G, DIKLIĆ M 2009 Variability of the Chloroplast DNA of Sessile oak (Quercus petraea agg. Ehrendorfer 1967) in Serbia. Arc Biol Sci 61 (3): 459-465. DOI: http:// dx.doi.org/10.2298/ABS0903459S

46. MIKIĆ T, ORLOVIĆ S, KOVAČEVIĆ B, MARKOVIĆ M, PILIPOVIĆ A 2009 Variability in wild pear (Pyrus pyraster Burgsd.) populations in Serbia based on leaf morphological characteristics. In: Orlović S (ed) Proceedings of International Scientific Conference Forestry in Achieving Millennium Goals, Novi Sad, Serbia, 13-15 November 2008. Institute of Lowland Forestry and Environment, Novi Sad, Serbia, pp 357-363

47. MIKIĆ T, ORLOVIĆ S, MARKOVIĆ M, KOVAČEVIĆ B, PILIPOVIĆ A 2008 Variability in service tree (Sorbus domestica L.) populations in Serbia. Lesnicky časopis - Forestry journal 54 (Supplement 1): 61-67

48. STOJNIĆ S, ORLOVIĆ S, PILIPOVIĆ A, VILOTIĆ D, ŠIJAČIĆ-NIKOLIĆ M, MILKOVIĆ D 2012 Variation in leaf physiology among three provenances of European beech (Fagus sylvatica L.) in provenance trial in Serbia. Genetika 44 (2): 341-353. DOI: http:// dx.doi.org/10.2298/GENSR1202341S

49. ŠTAJNER D, ORLOVIĆ S, POPOVIĆ B, KEBERT M, STOJNIĆ S, KLAŠNJA B 2013 Chemical parameters of oxidative stress adaptability in beech. Journal of Chemistry. DOI: http://dx.doi. org/10.1155/2013/592695

50. ORLOVIĆ S, ERDEŠI J, RADIVOJEVIĆ S, OBUĆINA Z, JANJATOVIĆ G 2001 Seed orchard of oak (Quercus robur L.) - a basis for further refinement in Srem (in Serbian). Šumarstvo 1: 1-9 
51. ORLOVIĆ $S$, ŠIMUNOVAČKI Đ, ĐORĐEVIĆ $Z$, PILIPOVIĆ A, RADOSAVUEVIĆ N 2008 Conservation of genetic resources and seed production of oak (Quercus robur L.) (in Serbian). Monograph: 250 years of forestry in Srem, JP Vojvodinašume

52. TRUDIĆ B, GALOVIĆ V, ORLOVIĆ $S$, PAP P, PEKEČ $S$ 2013 A strategy for the identification of candidate gene for drought induced stress in penduculate oak (Quercus robur L. (Q. Penduculata EHRH.), Fagaceae. Bulgarian Journal of Agricultural Sciences 19 (2): 338-246

53. NONIĆ M, VETTORI C, BOSCALERI F, MILOVANOVIĆ J AND ŠIJAČIĆ-NIKOLIĆ M Genetically modified trees - State and Perspectives. In: Book of abstracts of IV Symposium of the section of the breeding of organisms of the Serbian Genetic Society, Kladovo, Serbia, 2-6 October 2011, pp 107

54. TRUDIĆ $B$, KEBERT M, POPOVIĆ MB, ŠTAJNER D, ORLOVIĆ S, GALOVIĆ V 2012 The level of oxidative stress in poplars due to heavy metal pollution in soil. Baltic For 18 (2): 214-227

55. TRUDIĆ $B$, KEBERT M, POPOVIĆ MB, ŠTAJNER D, ORLOVIĆ S, GALOVIĆ V, PILIPOVIĆ A 2013 The effect of heavy metal pollution in soil on Serbian poplar clones, Sumar list 137 (5-6): 287-296

56. KEBERT M, TRUDIĆ B, STOJNIĆ S, ORLOVIĆ S, ŠTAJNER D, POPOVIĆ MB, GALIĆ Z 2011 Estimation of antioxidant capacities of poplar clones involved in phytoremediation processes. In: Proceedings of STREPOW International workshop, Andrevlje-Novi Sad, Serbia, 23-24 February 2011, pp 273-280

57. ŠTAJNER D, ORLOVIĆ $S$, POPOVIĆ MB, KEBERT M, GALIĆ M 2011 Screening of drought oxidative stress tolerance in Serbian melliferous plant species. Afr J Biotechnol 10 (9): 1609-1614. DOI: http://dx.doi. org/10.5897/AJB10.485

58. GALOVIĆ $V$, SZABADOS L, ORLOVIĆ S, FLADUNG M, TRUDIĆ B, PEKEČ S 2012 Platform for testing different stress inducible genes on Poplars. Govedar Z, Dukić V (eds) Book of abstracts of International Scientific Conference - Forestry science and practice for the purpose of sustainable development of forestry, 20 years of the Faculty of Forestry in Banja Luka, Republika Srpska, Bosnia and Herzegovina, 1-4 November 2012. Faculty of Forestry, Banja Luka, Bosnia and Herzegovina, pp108
59. GALOVIĆ V, FLADUNG M, SZABADOS L, ORLOVIĆ S, TRUDIĆ B 2012 Improving tolerance to drought and saline stresses of poplar clones using GRAS/SCL TF, a gene encoding a transcription factor. In: Govedar Z, Dukić V (eds) Book of abstracts of International Scientific Conference - Forestry science and practice for the purpose of sustainable development of forestry, 20 years of the Faculty of Forestry in Banja Luka, Republika Srpska, Bosnia and Herzegovina, 1-4 November 2012. Faculty of Forestry, Banja Luka, Bosnia and Herzegovina, pp107

60. VALENZUELA S, STRAUSS S 2005 Lost in the woods. Nat Biotechnol 23 (5): 532-533. DOI: http://dx.doi. org/10.1038/nbt0505-532

61. WILLIAMS CG 2005 Framing the issues on transgenic forests. Nat Biotechnol 23 (5): 530-532. DOI: http://dx.doi.org/10.1038/nbt0505-530

62. ERIKSON ME, ISRAELSSON M, OLSSON O, MORITZ T 2000 Increased giberellin biosynthesis in transgenic trees promotes growth biomass production and xylem fiber length. Nat Biotechnol 18 (7): 784-788. DOI: http://dx.doi.org/10.1038/77355

63. FLADUNG M 2004 Gene technology and proteomics. In: Kellison R, McCord S, Gartland KMA (eds) Forest Biotechnology in Latin America, Proceedings of the Forestry Biotechnology Workshop, Global Biotechnological Forum, Concepción, Chile, 2-5 March 2004. Institute of Forest Biotechnology, Raleigh, USA, pp 73-79

64. VALENZUELA S, BALOCCHI C, RODRÍGUEZ J 2006 Transgenic trees and forestry biosafety. Electron J Biotechn 9 (3): 335-339. DOI: http://dx.doi. org/10.2225/vol9-issue3-fulltext-22

65. RANKOVIĆ N, KEČA $\sqcup 2005$ An Action Plan for the establishment and revision of the National Forest Programme in Serbia. Int For Rev 7 (1): 63-70. DOI: http://dx.doi.org/10.1505/ifor.7.1.63.64161.

66. FENNING TM AND GARTLAND KMA 1995 Transformation protocols for broadleaved trees. Methods in Molecular Biology. 44: 149-166. DOI: http://dx.doi.org/10.1385/0-89603-302-3:149 